\title{
TREES, EARTH, WATER, AND ECOLOGICAL UPHEAVAL: LOGGING PRACTICES AND WATERSHED PROTECTION IN CALIFORNIA
}

That nature's forces are in delicate balance is widely accepted as a truism. That man and his works are almost totally dependent on the preservation of this balance is less appreciated. The recent tragic floods in Northern California have repeated the lesson for us, slowing that in any stream system; earth, rock, water, vegetation, fish and animal hfe act each upon the other, and the smallest change in any of these elements will set up a chain reaction. The end result may be an ecological upheaval profoundly significant both to the environment and to the men who are inescapably a part of it. This Comment will show how one activity within a watershed environment, logging, may, if inadequately regulated, contribute to such an upheaval, helping to cause erosion, floods, and the consequent destruction of the watershed. Concentrating on the river systems of California's north-coast region, the Comment will examine the relation between watershed protection and land use in general; then it will speak of logging practices in particular; finally, it will criticize California's attempt by statute to regulate the relation between the logger and his land.

\section{I}

NORTHWEST CALIFORNIA

\section{A. A Vulnerable Land}

California's three northwestern counties, Mendocino, Humboldt, and Del Norte, are, with their steep slopes, torrential rains, and often junglelike tangles of vegetation, the caricature of an area where improper land use can immeasurably intensify the blows delivered by an already capricious nature. Aside from some crystalline strata in the Klaunath Mountains, the soils are generally sedimentary and consequently quite unstable. ${ }^{1}$. That this instability is closely related to land use is shown by the estimate that whereas only one per cent of the land would present an erosion problem if left untouched; twenty-five per cent is erosible if the native vegetation is removed. ${ }^{2}$

The most unstable lands are largely on the steep upper slopes of the Eel River drainage where the only ground cover is grass or clraparral. These slopes have hittle infiltration capacity, and when saturated they are highly subject to landslips which result in tons of silt being washed into the

1 Hearings Before the Cal. State Bd. of Forestry at S-2 (Feb. 26, 1965) [hereinafter cited as Hearings].

2 Id. at S-3. 
streams. ${ }^{3}$ The rest of the land in the region is largely forested; the ground is covered with many inches of forest litter, and if left untouched, remains quite permeable and well drained. But two thirds of the three-county region is commercial timberland, subject to varying degrees of disturbance, and may be very erosible when the rains come. ${ }^{4}$

\section{B. Floods and the Sociology of the Northwest}

And the rains do come. Parts of Del Norte County often get a hundred inches of precipitation in a year, much of which may be concentrated in extended storms such as occurred in 1955-56 and 1964-65. Without vast levees and reservoirs such as now exist in the Central Valley, and with few high mountain snowpacks to retard runoff, 10.4 million acre feet of water drained from the north Coast Ranges into the Pacific during seven December days in $1964 .^{5}$ Dozens of small towns, like Orick, Klamath, and Pepperwood, vulnerably situated in low alluvial plains, were inundated. These lowlands were battered by tons of slash, cut logs, and whole trees washed down the rivers; worst of all was the three to six-foot layer of silt left behind by the receding waters-soil washed off the slopes of watersheds exposed to the torrents.

What caused the floods? Despite the rather primitive state of our knowledge of watershed ecology, one thing we can say is that the question is far more complex than many of its emotional disputants would have us beheve. Justice Douglas blames everything on reckless logging, ${ }^{0}$ totally ignoring many other possible contributory causes such as unusually high rainfall, highway and hydro-electric projects, fire; and land-use conversion. ${ }^{7}$ On the other hand, the local population, seventy per cent of whose economy depends upon the lumber industry, is almost childlike in its belief in the sanctity of the timber owners and operators. The big issues on the north coast are conservation ones: halting the harvest of virgin redwoods, controlling the stench and air pollution caused by pulp mills, putting highways through state parks. Public opinion stands on every issue with the companies. ${ }^{8}$ It is no different when it comes to assigning causes for the

3 Id. at 29-34 (remarks of S. Pyle, Chief of Planning, North Branch, Dep't of Water Resources).

4 Id. at $17-24$.

5 Id. at S-1.

6 "But dams cannot control the real causes of floods in northern California. Reckless logging has stripped that area of its native ability to retard, absorb and contain rainfall. . . . In the 1964 floods unlogged streams ran full but crystal clear. Only the logged ones filled the ocean for miles with the soil of what had been great redwood forests." Dovoras, A WIIDERNESS BIIL OF RIGHTS 129 (1965).

7 See Briegleb, The Wasted Woods, 63 J. Forestry 697-98 (1965).

8 "When most of the enployment is offered by the forest industries, when most of the money is brought into the region by those industries, when most subsidiary businesses depend 
yearly havoc wrought by the region's streams. Local opinion was echoed by the Humboldt County official who said, "Logging operations made no appreciable difference in view of the rainfall amounts on already saturated soils. Highly productive soils are quick to regenerate after logging." Unless we resolve this dispute, it would be presumptuous to pass judgment on the adequacy of California's regulation of forest practices. We must, therefore, examine what may cause floods in general, and, specifically, whether logging is a factor in California's floods.

\section{II}

FLOODS, EROSION, AND IAND USE

\section{A. General}

Flood conditions arise when precipitation over a given period exceeds the amount of water lost through evapotranspiration and the amount absorbed by the watershed's natural and artificial storage facilities. ${ }^{10}$ Seizing upon this formula, some might say that since the north coast is always subject to unusually heavy rainfall; it will always have fioods regardless of land-use practices. These people would be correct insofar as the region does get exceptionally heavy rains, and insofar as its lack of storage facihities in the form of large snowpacks and artificial reservoirs cannot be blamed on unregulated logging or grazing. However, other major means of water storage, underground basins and the soil itself, are quite dependent upon land use for their efficacy. This is because when land is overused and left exposed to the elements, it becomes less permeable and loses the infiltration capacity necessary if the water is to be absorbed and not rush immediately into the drainage system. Therefore one must distinguish between the volume of total runoff during and after a storm, and the peak discharge, that is, the highest water level during a storm period. Total runoff is always high, even in an untouched watershed. However, discharge-peaks are often postponed or lessened in ferocity by ground storage facilities whose efficacy is directly related to land use. ${ }^{11}$

\section{B. Logging Practices and the Land}

In addition to hindering underground storage of rainfall, land use may worsen the landslips, stream-bank undercutting, and erosion which have

for their prosperity upon the continued production of forest products, it is difficult for the people of the region to be objective or take a broad view." Dasasans, The Destruction of CAIIFORNIA 90-91 (1965).

8 Hearings at 37 (remarks by Sam Mitchell, Supervisor, Humboldt County).

${ }^{10}$ Id. at 47-52 (remarks by Paul Zinke, Professor of Forestry, University of California, Berkeley).

11 Chapman, Effects of Logging Upon Fish Resources of the West Coast, 60 J. ForesTRY 533 (1962). 
caused so much havoc in northwest California. Here, watershed protection and logging practices have become vitally interrelated. Since 1945 this part of California has become the last area in the United States where vast stands of privately owned timber have been opened to massive exploitation. ${ }^{22}$ While redwood had long been cut on the bottomlands in areas adjacent to ocean and rail transportation, the post-war building boom sent the lumberman to steeper inland slopes covered with douglas fir. On these precipitous mountainsides, modern heavy equipment and cutting techniques are, according to many, more destructive of the land than were older, more haphazard harvesting programs. ${ }^{13}$ These automated procedures combined with the adoption of clearcutting methods in redwood areas, led to the criticism that "nowhere else in California in recent decades has conservation of the land's resources been held more in abeyance."14

How may specific logging practices result in soil erosion and all the evil effects which accompany it? Perhaps the most pertinent answers to this question may be found by examining the practice rules enforced within the Six Rivers National Forest, which encompasses areas immediately adjacent to the private timberlands with which we are concerned. The United States Forest Service, whicl administers Six Rivers, has as a major goal the protection of watersheds, and includes specific regulations regarding forest practices in all contracts concluded with operators who harvest timber on federal lands. ${ }^{15}$ No similar provisions are required by California for the operator to get a permit to cut on private lands.

Logging roads and skid trails appear to be most important in causing silt-laden rainwater to flow into streams sooner and faster. Roads, and the

12 In Oregon and Washington, much timber producing land was publicly owned, and thus subject to Forest Service regulation. Furthermore, logging in this region has long been in the hands of the big companies, like Weyerhauser, Simpson, and Georgia Pacific, who of necessity must preserve their lands intact so as to make sustained yield production possible. In contrast, Califorma's redwood lands are overwhelmingly in private hands, and the fly-bynight logger still plays an important role in the industry. DaSaANN, op. cit. supra note 8, at 85 .

13 Woodridge, Watershed Disturbance From Tractor, Skyline Logging, 58 J. FORESTRY 369 (1960).

14 Dasmann, op. cit. supra note 8 , at 84 .

15 Hearings Before the Assembly Interim Comm. on Fish and Game at 94-100 (Oct. 10, 1961) (remarks by Wes Spinney, Supervisor, Six Rivers National Forest) [hereinafter cited Assembly Hearings]. It slould be noted that many feel that even the Forest Service is often too lenient in issuing and setting conditions for logging permits. Some blame this on pressure from the loggers and local commumities, as well as on the general lack of ecological knowledge even among foresters. Dasmans, op. cit. supra note 3 . Justice Douglas adds to this the desire of the bureaucrat to use timber revenues as a budget-balancing factor. Douchas, op. cit. supra note 6, at 92-93. Others say the Forest Service may lose sight of conservation objectives in its "yen for mass recreation such as ski lifts and scenic automobile roads." Christian Science Monitor, Nov. 22, 1965, p. 5, col. 1. 
fill slopes associated with them, result in compacted soil, devoid of vegetative cover and useless as a storage facility. While some roads are necessary to any logging project, the number of roads needed is greatly affected by the methods utilized by the timber operator..$^{16}$ Whereas tractor logging in a typical douglas fir area may result in the denuding of as much as thirty per cent of the land area, only ten per cent may be exposed by cable logging methods, and use of the most modern skyline cranes may reduce the need for roads even more. ${ }^{17}$ Realizing this, the Forest Service classifies its lands as to steepness, soil characteristics, vegetation types, and storm intensity. Those areas that are most erosible may be closed to all activity. Other lands will be opened to cable logging only; less steep and more stable slopes may be logged by tractors.

Not only is the number of roads kept to a mimimum, but their location is also controlled. Running tractors and trucks up and down a streambed will often turn a clear-running watercourse into little more than an open ditch filled with silty, slash-laden water. Therefore, streams cannot be used as roads and crossing points must be kept to a minimum. Buffer strips of untouched vegetation between eiglit and thirty feet wide have proven highly effective in preventing silt from reaching streams; slash sediment barriers may help serve the same purpose. ${ }^{18}$

Finally, the Forest Service insists that provision be made to repair the damage which is unavoidable even in a well-planned operation. Surface runoff must be dispersed on bare hillsides. Slopes and roads must be reseeded, spur roads obliterated, and slash removed..$^{19}$ Nature is prodigal with her powers of renewal-if given half a chance. ${ }^{20}$

\section{Results of Unregulated Logging: The Multiplier Effect}

Unfortunately, Forest Service Standards are not emulated on the private lands where most of the logging in northwest California occurs. Nor do the California statutes, which rely largely on voluntary compliance

${ }^{16}$ See Haupt \& Kidd, Good Logging Practices Reduce Sedimentation, 63 J. ForeSTRY 664 (1965). Buffer strips thirty feet wide around all water courses will reduce practically all sediment from logging roads. See generally $i b i d$.

${ }^{17}$ Skyline logging makes use of aerial cables which move logs to their landing poimts by gravity. One experimental project found that whereas tractor logging resulted in $22.4 \%$ of the area being exposed, skyline logging exposed only $5.4 \%$ of the soil. By standard methods, ten miles of road were needed for every thousand acres; newer techniques required only one mile of road for every thousand acres. Woodridge, supra note 13, at 369-71.

18 See generally Haupt \& Kidd, supra note 16.

19 Assembly Hearings at 94-96 (remarks by Wes Spinney, Supervisor, Six Rivers National Forest).

20 One West Virginia experiment showed that an operation with selective cutting and planned roads produced only one-eleventh the stream siltation produced by an operation marked by clearcutting and unplanned roads. See Assembly Hearings at 164 (remarks by Walt Hopkins, Chief, Division of Watershed Management, U.S. Forest Service). 
and bona fides, really attain their end. One reason for this is that only the largest owners and operators have a real stake in watershed protection, since only they are in a position to produce on a sustained yield basis. The others are too often "gyppo" loggers who move quickly from job to job, leaving havoc in their wake, and starting a vicious cycle of erosion whose full implications may not appear for years to come. ${ }^{21}$

One of the saddest examples of such an ecological upheaval is that which has occurred in the Bull Creek watershed, a tributary of the South Fork of the Eel River. ${ }^{22}$ The area had remained largely intact until 1947; on its lower reaches was Rockefeller Forest, a state owned preserve of virgin redwood unmatched elsewhere. Then, between 1947 and 1954, fifty per cent of the upper slopes were denuded by fly-by-night operators. Fire completed the devastation and with the storms of 1954-55, there began a cycle of self-perpetuating erosion. On any stream, high waters will result in a certain amount of stream bottom erosion, that is, the shifting of gravel bars, and creation and filling of pools. ${ }^{23}$ But on Bull Creek, as water washed over the upper slopes of the watershed, the bared earth lost its infiltration capacity, thus increasing runoff in succeeding storms. This in turn intensified the erosion on the hillsides and raised the stream to such a level that its banks were undercut, especially in the Rockefeller Forest area. Banks and bluffs gave way; hundreds of the finest redwoods in the world were uprooted and hurled into the streambed. Although large scale logging in the watershed has ceased, the results of earlier reckless activities continue to be felt every winter. The state has found that the only solution would be to buy eighteen thousand acres of logged-over land and begin from scratch the task of rebuilding the watershed. The cost of the land alone would be one and one-half million dollars. ${ }^{24}$

Other delayed effects of watershed deterioration are less obvious but are perhaps more serious. Annong these is the decline of the anadromous fishery along California's north coast. The region's "six rivers," the Eel,

21 Senate Intertm Comac. on Straam and Beach Erosion, Finat, Report to LecistaTURE 17-20 (1957). There are some 1,700 timberland owners, and 1,500 timber operators in California. Id. at 19.

22 See generally The Tragedy of Bull Creek, Sierra Club Bull., Jan. 1960, p. 10,

23 In one control watershed which was left undisturbed, experimenters in December 1964 found that streams did run full and that debris increased by nearly ten times. However this "debris" was mainly stream-bottom gravel which always shifts considerably in high water. There were no bank undercuttings or landslips in the control watershed. Hearings at 53-57 (remarks of Robert Burgy, Professor, University of California, Davis).

24 The Tragedy of Bull Creek, Sierra Cluh Bull., Jan. 1960, p. 11. The vicious cycle whereby initial erosion results in higher water, which in turn causes more erosion, which in its turn leads to landships and fiash floods is described generally in the findings of the Senate Interim Committee on Stream and Beach Erosion. Finar. Report to Lecistature 129-30 (1957). 
Mad, Van Duzen, Smith, Klamath, and Trinity, have always been spawning grounds for millions of salmon and steelhead, which are the backbone of a multimillion dollar commercial and sport industry. The decline of the fishery to a quarter of its former extent has been attributed to many causes. Reservoirs in the Central Valley are insuperable concrete barriers against which thousands of fish batter themselves to death in a frantic effort to reach the gravel beds where they were born. Indians on the Klamath and Trinity, claiming treaty rights, are said to net spawning fish indiscriminately; loggers' slash blocks streams; highway and road builders blast hillsides into rivers and rechannel waters via iron culverts through which no fish can pass; pollution kills fingerlings. ${ }^{25}$ But beyond all these factors, the greatest "threat to salmon and steelhead are land use practices which are destroying the basic productivity of streams by promoting the flow of silt and debris from adjacent lands." ${ }^{26}$

The effects of irresponsible logging practices on fish life are innumerable. Abnormally high water flows result in gravel shifting which may kill up to ninety-five per cent of a fish's eggs before they hatch. ${ }^{27}$ Cutting of streamside vegetation tends to exaggerate temperature extremes in the water. Winter flows become abnormally cold, lengthening the incubation period of fertilized eggs; in the summer the water temperature will rise well above normal, decreasing the oxygen supply to fingerlings and making the stream a paradise for salmonid-killing bacteria. ${ }^{28}$ Finally, and most crucially; winter storms often turn a stream in a logged-over watershed into a river of mud. The author has seen dying salmon, heavy with roe, gasping in stagnant, muddy waters, hundreds of feet away from the stream channel they desperately sought. Often, fish finding themselves blinded by silt would be diverted into the smallest of clear-running tributaries. As the rains ended, the tributaries began to dry, and the stench of stranded and dying fish filled the air. The few eggs that were laid were smothered by thick layers of gummy silt.

25 See generally Assembly Hearings.

26 Id. at 134 (statement on behalf of W. T. Shannon, Director, Department of Fish and Game). Since 1955, some 925 miles of spawning streams have been damaged or destroyed by loggers. $I d$. at 123 .

27 Chapman, supra note 11 , at 534 .

$28 \mathrm{lbid}$. Lack of vegetation may cut down on losses of water by evapotranspiration during the summer, but this "benefit" from clearcutting is certainly offset by the fact that underground reserves will generally be at a lower level in a logged-over area. Another potentially dangerous situation may arise from chemical changes in the water caused by logging operations. These include the presence of more dissolved nitrates and phosphates, and pollution caused by the residue of burned slash. Ibid. In the pollution situation, of course, not only are the pollution sections of the Water Code applicable by the state, but the private riparian or the state can institute common law nuisance suits against other riparians who kill or hinder movement of migratory fish by pollution or slash barriers. People v. Truckee Lumber Co., 116 Cal. 397 (1897). 
The author's observations on the Smith, and conversations with knowledgeable persons, convince him that few if any salmon or steelhead were hatched on that river after the 1964-65 floods. Since the Smith is generally considered the clearest running of the "six rivers," it may be assumed that conditions were worse on other major streams.

For many, especially for those in the areas affected, the cure-all for the flood problem is the man-made reservoir. They point out that while both north-coast and Central Valley streams were filled with over twenty million acre feet of water during the Christmas 1964 storms, in the valley reservoirs and levees retarded the runoff of about seven tenths of the flow. Why not, the reasoning goes, tame the Eel, Klamath, and other northern rivers in the same way?

Without even considering that dams often deliver the coup de grâce to anadromous fish runs, and that they may be prohibitively expensive, a possibly decisive argument against the reservoir panacea is that many watersheds are now in such shape that any impoundments may be filled so rapidly with silt that their value as storage facilities would be nil. This is a perennial problem for many existing Califormia water projects: the Santa Ynez River has been dammed four times since 1920; yet as soon as reservoirs have been built, they have been filled with more mud than water. ${ }^{30}$ One of the chief planners for the Department of Water Resources has said that unless logging, grazing, and other sources of erosion on the Eel River are controlled, no serious talk of large storage facilities on this stream is possible." Professor Dasmann sums it up: "If we continue careless practices of land use on our major watersheds, our entire reservoir system will someday be converted into a series of flat alluvial plains through which the old rivers will cut their channels as they flow to the sea." 32

This has been an attempt to analyze undoubted problems which exist in the watersheds of northwestern California. United States Forest Service samplings have shown that the Mad River watershed is losing some 3,120 tons of sediment per square nile per year; on the Van Duzen, the figure is 5,300; on the South Fork of the Eel it is 8,950.33 The effects of this on

29 Hearings at 9 (remarks of W. P. Horn, Chief of Flood Operations, Dept. of Water Resources).

30 DasaranN, op. cit. supra note 8 , at 167-68.

31 Hearings at 29-34 (testimony of S. Pyle, Chief of Planning for the North Branch of the Department of Water Resources).

32 Dasmans, op. cit. supra note 3 , at 168.

33 The figures on sedimentation on California streams were compiled at the Pacific Southwest Forest and Range Experiment Station. Another California stream, Cache Creek, carried about 657 tons of sediment per year before being logged. One year, after $24 \%$ of the watershed was logged, the figure rose to 5,200 tons per year. Two years later the figure was still 1,700 tons. Oregon experiments show that when logging activity is increased by three times, siltation will rise $260 \%$. Assembly Hearings at 162-63. 
forests, fauna, and man are all too clear. Without saying that logging practices are the sole cause of the tragedy, it does seem that they are a major contributing factor. It is now necessary to examine what California's statutes have tried to say concerning the relation between the lumberman and the land.

III

THE FOREST PRACTICES ACT

\section{A. General Statutory History}

" 'We have virtually no forestry, and mighty little range management, game management, wildflower management, pollution control, or erosion control being practiced voluntarily by private landowners .... There is still no stigma in the possession of a gullied farm, a wrecked forest, or a polluted stream provided the project is a money-maker. " 234

This statement, regarding the sad situation of forest protection in the United States as a whole, is no less applicable to California, the nation's second largest lumber producer. The Spaniards attempted to control the harvesting of California's trees as early as 1813, but after the arrival of the "Anglos" in 1848, absolute laissez-faire was the rule until $1943 .{ }^{35}$ In that year, a law was passed forbidding the cutting of any conifer under eighteen mches in diameter, unless this was in accord with "good forestry practice."36 This provision was superseded by the $19^{2} 45$ passage of the Forest Practice Act. ${ }^{37}$ The Act, in amended form, has pre-empted all other forms, both state and local; of general forest practice regulation, save that of fire prevention..$^{38}$

Though recent amendments reveal an increasing suspicion of the ap-

${ }^{34}$ A statement in Aldo Leopold's Round River, quoted in DodgLas, op. cit. supra note 6, at $42-43$.

35 Arvola, Forest Practice Regulations in California, 60 J. Forestry 872 (1962).

36 Cal. Stats. 1943, ch. 172.

37 Cax. PUb. Resources CODE $\$ \S 4521-4618$.

38 Unlike California's Water Pollution Control Act which allows local governmental units to enact more stringent regulation than has the state (CAL. WATER CODE § 13001; People v. City of Los Angeles, 160 Cal. App. 2d 494, 325 P.2d 639 (1958)), the Forest Practice Act is considered to have pre-empted the field of general forest practice regulation from local political subdivisions. 28 Ors. CAL. Arr'y Gen. 190 (1956). It should be noted that common law nuisance suits may be a possible remedy against some of the effects of poor logging practices, for example, obstruction of fish passageways (Bohn v. Albertson, $107 \mathrm{Cal}$. App. 2d 738, 238 P.2d 128 (1951)). An argument might even be made that excessive siltation or residue from burned slash may constitute a nuisance to lower riparians. It is certainly not necessary that defendant have deposited the offending agent in the stream; if nornial seasonal drainage triggers a transitory nuisance, this is enough. People v. New Penn Mines, Inc., 212 Cal. App. 2d 667, 28 Cal. Rptr. 337 (1963). Likewise the common law definition of a pollution nuisance, "the econonric or aesthetic spoilage of water," might fit excessive siltation, though the statutory definition would not. $C f$. $i b i d$. This type of suit, even if possible, will in most cases be quite impractical due to the difficult if not impossible task of locating the original sources of siltation or slash barriers. 
proach, the statute's philosophy has always been one of self-regulation. The State Board of Forestry, a body composed largely of forest-land users, formally promulgates Forest Practice Rules for each of four Forest Practice Districts. The rules are actually written by local Forest Practice Committees, which are agam composed of timber owners and operators. ${ }^{30}$ When approved by two thirds of the timberland ownership in each district and by the Board of Forestry, the rules govern about eighty per cent of Cahifornia's annual timber cut.

Enforcement of the rules was put in the hands of the State Forester nominated by the Board and appointed by the Director of Natural Resources. It was not until 1957 that the Act included a permit system under which violations of the rules could be punished by the revocation of the operator's authorization to cut timber. ${ }^{40}$ Despite this change the Forester continued to find enforcement difficult, chiefly due to the time lag between the discovery of a violation and the imposition of a sanction. There were no injunction provisions, and with the various allowances for grace periods and public hearings, it was usually six months after discovery that a violation could be halted. ${ }^{41}$ By this time; the fly-by-night operator would long since have disappeared, or have subcontracted himself to another operator whose permit had not been revoked..$^{42}$ Furthermore, since no permit was required of the landowner, he could continue harvesting his timber regardless of the sanctions brought against an individual operator. Finally, monetary penalties were minimal, far below the cost of repairing the damage wrought by the logger. ${ }^{43}$

In 1963, further amendments were passed, aiming at some of these shortcomings. Temporary restraining orders followed by permanent injunctions are now available upon discovery of a violation. ${ }^{44}$ The land owner as well as the operator is now required to have a permit, so that if the latter disappears, the former is still subject to sanctions until the violation ceases and the damage is repaired ${ }^{45}$ Upon failure by the private parties to

39 The State Board has seven members; only one represents the public; others come, one each, as representatives of the following interests: the pine and redwood industries; forest land ownership; the range-livestock industry; agriculture; the beneficial use of water. CaI. Pub. Resources Code § 631. The local Practice Committees have five members. One is nominated by the Board and votes only in case of tie; the four voting members consist of one timber owner, one former timber orvner, and two private timber owner-operators. CaI. Pub. Resources Code $\$ 4564$.

40 CAL. Pub. Resources Code $\$ 4595$.

41 Raymond, Report on Compliance and Enforcement of the Forest Practice Act, 38 CALIFoRNIA PAMrperets 4 (University of Califorma Forestry Library 1962).

42 State Bd. of Forestrx, Enforcejanent of the Forest Practice Act-Spectat Report 6-8 (1957).

43 Berry, The Need to Revise California's Forest Practice Act, Sierra Club Bull., Oct, 1961, pp. 48-49.

44 Cal. Pub. Resources Code $\$ \S 4612-13$.

45 Cat. Pub. Resources Code $\$ 4618$. 
correct damages, the State Forester may do so and recover by civil suit up to forty dollars an acre. ${ }^{46}$

\section{B. Critique}

Despite these improvements, a close examination of the Act and of the local Forest Practice Rules indicates that the self-regulation theory remains essentially fallacious. ${ }^{47}$ The State Board of Forestry is composed largely of men representing the lumber industry or other land owner-users whose interest and knowledge of overall watershed management problems is at best minimal. The District Committees, which actually formulate local forest practice rules, are exclusively composed of timber owners and operators who inevitably possess the same disabilities. The one person who is most directly concerned with overall management and enforcement problems, the State Forester, is relegated to an advisory role. The original hope was that such self-regulation would mean that "when such rules were put into effect, timber owners surely would take more cognizance of their methods ... and thereby gradually improve cutting practices without compulsion by the state." ${ }^{38}$ Yet the most cursory examination of the Forest Practice Rules of the Redwood Forest District, which do not differ appreciably from those of the other districts, ${ }^{40}$ shows the "general lack of understanding on the part of the logging operators" the rules somewliat less than efficacious as a tool of watershed management.

It will be remembered with what specificity the Foresters of the Six Rivers National Forest impose restrictions on operators who cut trees on federal land. ${ }^{51}$ The individual tracts of land involved are graded as to their erosibility, and specific rules of conduct are included in the contract concluded between the government and the logger. California's Forest Practice Rules are not hobbled by any such specificity; in the realm of watershed protection; they say nothing at all of fish, wildlife, or recreational values. They make no attempt to distinguish different lands as to hazard class, or to urge that at times cable. rather than tractor logging should be required. The possible need for vegetative buffers along streams goes entirely unmentioned.

\footnotetext{
46 CAL. Pub. Resources Code $\$ 4615$.

47 A conclusion also reached by Emanuel Fritz, the author of the original 1945 Forest Practice Act. "Self-regulation has failed for various reasons after twenty years of educational effort." Senate Interdac Comm. on Beach and Stream Eroston, Finat Report to IfeistaTURE 14 (1957).

48 Arvola, Forest Practice Regulation in Califormia, 60 J. ForestRY 872 (1962).

49 The Forest Practice Rules for each district may be found in 14 CalIF. Adm. Code $\$ \S$ 910-49. Those of the Redwood District are at 14 CALIF. ADM. CoDE, §§ 910-19.

co Senate Intertar Comar. on Beach and Stream Eroston op. cit. supra note 47, at 10 (remarks of R. M. Paul, Water Projects Co-ordinator, Dep't of Fish and Game).

51 See notes 15-19 supra and accompanying text.
} 
Nor are the Rules any more explicit when it comes to the most important factor in a poorly managed operation: the logging road. The Rules speak of roadbuilding only in the form of vague encouragements to avoid "undue erosion." No prohibition against using streambeds as roadways exists, only a requirement that this practice not result in "excessive erosion"; "due diligence" is to be exercised in crossing streams; "gouging of same will be kept to a minimum." role of the Forester who asks a, court to enjoin a given practice. Since the Rules forbid no specific activity, the court has little if any guide from which to work. Though the injunction is meant to prevent conditions of larm from arising, the Rules couch their few standards in terms of "excessive erosion," which may not appear for months, or years, after the practice has occurred and the operation completed..$^{54}$

The statute also provides means whereby one can cut timber free of even these Rules, imprecise though they may be. Any harvester can submit an "alternate plan" for cutting, which plan, upon approval of the District Committee, supersedes the requirements of the Rules. ${ }^{55}$ Another, and far more important avenue of escape is provided by the "conversion feature" whereby any land, regardless of its silvicultural capacities, erosibility, or overall role in the watershed may be converted to nonforest uses. A simple affidavit of bona fides enables the individual to clearcut his land of all vegetation, regardless of the Forest Practice Act. ${ }^{50}$ By 1961, 676,895 acres lad been so "converted," among which were the lands whose devastation was the initial cause of the Bull Creek disaster. Even the forest products industry has alluded to the role played by land-use conversion in damage to the Klamath; Mad, and Eel Rivers, and there seems little doubt that "often the worst violations of forest practices brought to the attention of the state are upon such lands."

Even if there were no conversion loophole, and even if the Rules were rigorous and specific, it is questionable whether the less enlightened logger would be deterred from violating state standards. Unlike a national forest operation, which may be inspected for compliance with required standards as much as three or four times a week, the average logging operation on private land is inspected "far less than once a year,"

5214 CAT. ADMr. CODE $\$ \S 914.9,944.6$.

53 14 CAL. ADM. CODE $\$ 914.9$.

54 State BoArd of Forestry, Enforcenent of the forest Practice Act-Spectat REPORT 8 (1957).

55 Car. Pub. Resources Code $\$ \S 4574-75$.

so Cat. Pub. Resources Code $\$ 457 \%$.

57 Arvola, supra note 48 , at 875 .

58 Berry, The Need to Revise California's Forest Practice Act, Sierra Club Bull., Oct. 1961, pp. 44, 49. 
hundred timber operators in California, many of whom liave several operations. Yet the legislature has budgeted for only eight inspectors for the entire state. Of 2,440 inspections made in 1961, 1,778 infractions were found. A 1958 estimate was that sixty-three per cent of all operators were to some degree not complying with the Act.59 Yet is this surprising? "No one would trust his life to the higlwways if highway patrolmen were encountered on them by the average motorist only once a year; it is overoptimistic to believe that all lumbermen will maintain good practices unless the apprehension of offenders is a real probability ...."160

It should not be inferred that California's law is an especially weak one. Oregon's Conservation Act, ${ }^{61}$ also based on the self-regulation theory, does not even consider that watershed management and the avoidance of erosion might be among its goals. Theoretically, its enforcement provisions should be stricter than California's: The State Forester must, by statute, inspect all operations at least once a year. ${ }^{62} \mathrm{He}$ also may reclassify converted land into forest land subject to regulation if he finds the owner to be operating in bad faith, ${ }^{63}$ and upon discovering a violation, he can require the posting of a cash deposit or surety bond to guarantee that reparation will be made. ${ }^{64}$ Yet, even with these features, observers have found enforcement of the Act to have been "shallow," entirely too subject to the varying stresses of interest lobbying during times of economic recession..$^{65}$ Finally, Oregon's law; like California's, contains no meaningful rules regarding tractor logging, placement of roads, and protection of fish life.

\section{Reformation}

The relationship between flora and fauna, soils and precipitation, in northwest California is clearly complex. Yet the efficiency of modern logging methods and the rapid deterioration of watershed lands make time of the essence. Some had hoped that an integrated regional program would be possible with the completion of California's Soil Vegetation Survey Program. ${ }^{66}$ It has been estimated, lowever, that at present rates of

59 The Redwood Forest Practice District had the lowest compliance index in the state. This index is the ratio of the total number of rules obeyed to the total number of rules obeyed plus those broken. The overall California index was .87; the Redwood District's was .83. Arvola, supra note 48 , at 873-75.

${ }^{60}$ Berry, California's Forest Practice Act: A Progress Report, Sierra Club Bull., Dec. 1964, pp. 65-66.

61 ORE. REv. STAT. \$\$ 527.010-527.240, 527.990(1) (1961).

62 ORE. Rev. Stat. \$ 527.140 (1961).

63 ORE. ReV. STAT. \$ 527.130 (1961).

64 ORE. ReV. STAT. \$ 527.190 (1961).

65 Stacer, The Oregon Conservation Act, 2 Writaadetre L.J. 268, 273 (1962).

${ }^{66}$ Authorized by $\$ 4672$ of the California Public Resources Code. 
progress complete information on the state's soil and vegetation types will not be available until $1985 .{ }^{67}$ Therefore the best approach for the present would be to tighten our forest practices regulation scheme as follows:

First, unrestricted conversion of forest land to highly erosible grasslands must be ended. In especially unstable areas, such conversion should not be allowed, and in any case, the State Forester should be able to reclassify lands converted without regard to soil conservation principles. Upon reclassification, the lands would again be subject to the Forest Practice Rules. ${ }^{68}$

Second, local Forest Practice Rules should include specific provisions controlling logging practices in accord with the terrain, soil chemistry and stability, and vegetation characteristics of the lands involved. Tractors should be excluded from steeper areas. Streambeds should not be used as roadways or landings, and should be protected by vegetative buffers everywhere. Perhaps permits to cut should be conditioned on the submission of advance plans including locations of proposed roads, landings, and skid trails. ${ }^{69}$ In short, the rules and the permits issued under them should provide the State Forester with standards so specific that violations will be readily apparent to any court asked to enjoin them.

Third, the number of inspections of going operations should be greatly increased. Perhaps, hike Oregon, California should ensure by statute that every operation in the state is checked at fixed intervals. ${ }^{70}$

Finally, the self-regulation theory should be modified. Walter Gellhorn early pointed to the basic fallacy of such a system:

It is common observation that ... organizations originally intended to be policemen of economic activities often become almost the guardian angels of those they were to police .... 'Nothing is so dangerous in a democracy as a safeguard which appears to be adequate but is really a facade....' It nlust be remembered that the unorganized public interest is represented by the agency and that there is today no effective substitute for that type of representation. Self government, even under some form of generalized and official auspices, cannot always be relied upon to assay properly the collateral interests which inay be affected. ${ }^{11}$

The fact is that even were our ecological knowledge very highly developed, certain basic public policy decisions would have to be made before

67 Berry, supra note 58 , at 47.

68 Wallis, Factor Analysis of SoIl. Eroston and Streadr Sedimentation in Northern CaItrornda 90-94 (1965).

69 See U.S. Forestry Service, Dep'T of Agriculture, GuDe to Eroston Reduction oN National, Forest Ttmber SaIe Areas: CaIfrornia Region (1954).

70 See note 61-65 supra and accompanying text.

71 Gelimorn, Federal Admintstrative Procendngs 131-33 (1941). 
Forest Practice Rules were formulated. The economic well-being of the regions affected, the future policy of the state regarding its water resources and their distribution, and aesthetic considerations must all be balanced. Yet the decision is made by a State Board and local Committees wedded to only one of these interests. The Rules promulgated reflect not the silvicultural knowledge of the State Forester, or the ichthyological knowledge of the Fish and Game biologists, or the influence of the hydrologists and soil scientists, but only "the consensus of those concerned, mostly people in the timber industry ...."72 Though present watershed deterioration presents a far more complex problem than that presented, for example, by placer mining in an earlier era, we still have no single agency that has the authority, the expertise, and the incentive to deal with our watersheds as a whole. While few would deny that many of the larger companies are beginning to take a long view as regards their own lands, the lack of substance in the Forest Practice Rules indicates that many others remain ignorant, or uncaring, of the real implications of poor logging practices.

A legislature establishing an agency and desiring it to act in the public interest has two alternatives to the pure self-regulation theory: It may provide for wider interest representation on the agency itself, or it may authorize a board entirely composed of noninterested parties, relegating the partisans to a purely advisory role. For political reasons; the latter alternative may be impossible for the Califorma State Board of Forestry and the local committees. But the first alternative may be more feasible, and, at the very least, the conservationists, biologists, and lrydrologists should get equal representation with the lumber industry on these agencies.

Finally, the public slould insist on influencing the rule-making process to the maximum extent presently authorized by statute. The Board is explicitly bound by the California Administrative Procedure Act in its

72 Arvola, supra note 48 , at 875 . The presence of experts on the Board is not the whole answer. Many object to the policy nuaking procedures in the United States Forest Service on the ground that while the Service has access to all the experts, it renuains essentially proindustry, with little sympathy for the public ainis of forestry. See generally Reich, The Public and the Nation's Forests, 50 CaLIF. L. REv. 381 (1962).

The California State Board of Forestry has been just as provincial. Just one example: Recently the Board came out against taking private lands for a proposed Redwood National Park. San Francisco Chromicle, Dec. 3, 1965, p. 8, col. 2. The nub of their argument is that this proposal would thwart the conpanies' sustained yield plans which would prevent the econony of the north coast fronl declining as old growth timber is cut. This stand is taken directly in the face of figures showing that these companies, who are cutting nearly all old growth timber, are harvesting twice the number of board feet per year that the forests are reproducing. In sixteen years, there will be no old growth redwood left on commercial lands; yet there is nowhere near enough new growth to take up the slack. In short, the Board policy, if followed, will mean that ultinately we will have neither trees, nor a park, nor jobs. See Dasarann, The Destruction of California 93-98 (1965). 
adjudicative functions. ${ }^{73}$ It should be as clear that rule-making procedures are also subject to the Act. ${ }^{74}$ This means that any private party so wishing may receive mailed notice of Committee hearings, and that any "interested party" has a right to submit written arguments and statements which must be considered by the agency in adopting or amending the Forest Practice Rules. ${ }^{75}$ While the definition of an "interested party" is unclear, it would certamly seein to include local residents affected by floods as well as conservation and sportsmen's organizations. Were these groups to ask specific changes in the Rules, as is their right, ${ }^{76}$ they would at least have alerted the citizenry in general to any heavy-handedness by the industry.

Thoreau said that a man is rich in proportion to the things he can afford to leave alone. ${ }^{7 \pi}$ The economic argument is heard everywhere on the north coast: The region cannot "afford" to set aside redwood parks, or to keep pulp mills out of urban areas, or to regulate logging practices. Yet may not one argue that the balance sheet should include more than the profit and loss statements of the Arcata or Miller Lumber Companies? That it should include the fact that the salmon runs on the Klamath, Mad, and Eel Rivers are one-quarter of what they once were, and that every square yard of soil in these watersheds is losing an average six pounds each year by erosion? ${ }^{78}$ In short, we are losing the land; and unless we can afford to leave the land alone, "sustained yield"-in the form of parks, forest products, fish and wildlife - will be more than "harmless puffing" by industry spokesnen; it will be the cruellest of illusions.

David M. Wilson

73 Cas. Pub. Resources Code $\$ \S 4589,4595$.

${ }^{74}$ The rule-making provisions of the Administrative Procedure Act are generally applicable when regulations are promulgated by "any" agency pursuant to a grant of "quasi-legislative power." Exceptions in the Act itself are strictly construed and subsequent legislation is deemed not to create new exceptions unless it explicitly does so. CAL. Gov'T CODE \$§ 11371, $11420,11421$.

75 CAL. Gov't CODE $\S \S 11423,11425$.

76 CAL. Gov't CODE $\$ \S 11426,11427$.

77 Thoreat, Walden, in Peopie, Pranciples, and Politics 94 (Meltzer ed. 1963).

78 Gilliam, The Big Soil Robbery, San Francisco Sunday Examiner \& Chronicle, Dec. 12, 1965, This World, p. 26, col. 2. 